\title{
SINTESIS 2,6-BIS(2'-HIDROKSIBENZILIDIN)SIKLOHEKSANON DARI HIDROKSIBENZALDEHID DAN SIKLOHEKSANON DENGAN KATALIS NATRIUM HIDROKSIDA
}

\author{
Adam M. Ramadhan ${ }^{1}$, Dwi Utami' ${ }^{2}$, Sardjiman $^{3}$ \\ ${ }^{1}$ Laboratorium Penelitian dan Pengembangan FARMAKA TROPIS Fakultas Farmasi \\ Universitas Mulawarman, Samarinda, Kalimantan Timur \\ email:adam@farmasi.unmul.ac.id \\ ${ }^{2}$ Universitas Achmad Dahlan, Yogyakarta \\ ${ }^{3}$ Universitas Gadjah Mada, Yogyakarta
}

\begin{abstract}
The synthesis of ciklovalon (HGV-0) analogue was done by substituent modification on aromatic ring. One of the ciklovalon analogues is 2,6-bis(2'hydroxybenzylidene)cyclohexanone. The objective of this study was obtaining the amount of mol $\mathrm{NaOH}$ catalyst in order to find the highest rendement. The synthesis of 2,6-bis(2'hydroxybenzylidene)cyclohexanone has been done using aldol condentation reaction from 2'-hydroxybenzaldehyde and cyclohexanone. The variation of mol catalyst $\mathrm{NaOH}$ used in this research were 0.2 mole; 0.4 mole and 0.8 mole. The synthesized product was purified by recrystalization with ethanol and cold water. The structure of the synthesized compound was determined by $U V$-Vis, IR, ${ }^{1} H-N M R$, and GC-MS. The result showed that the average rendement the variation of mol catalyst $\mathrm{NaOH} 0.2$ mole; $0.4 \mathrm{~mol}$ and 0.8 mole were $(25.12 \pm 0.86) \%,(11.23 \pm 0.40) \%$ and $(9.50 \pm 0.56) \%$. The highest rendement was obtained when the 0.2 mole $\mathrm{NaOH}$ used. Statistical analysis using tukey test resulted significant differences. The spectroscopic analysis using UV-Vis, IR spectrometry, ${ }^{1} H$-NMR spectrometry, and GC-MS showed that synthesized compound was 2,6-bis(2'hydroxybenzylidene)cyclohexanone.
\end{abstract}

Keywords: 2,6-bis(2'-hydroxybenzylidene)cyclohexanone, synthesis, catalyst, rendement

\begin{abstract}
ABSTRAK
Sintesis analog siklovalon (HGV-0) dilakukan melalui modifikasi substituen pada cincin aromatiknya. Salah satu analog siklovalon tersebut adalah 2,6-bis(2'hidroksibenzilidin)sikloheksanon. Tujuan penelitian adalah untuk mengetahui jumlah mol katalis $\mathrm{NaOH}$ yang menghasilkan rendemen paling besar. Sintesis 2,6-bis(2'hidroksibenzilidin)sikloheksanon dilakukan melalui reaksi kondensasi aldol dari 2hidroksibenzaldehid dan sikloheksanon dengan menggunakan katalis natrium hidroksida. Variasi jumlah mol katalis $\mathrm{NaOH}$ yang digunakan dalam penelitian ini adalah 0,2 mol; 0,4 mol dan 0,8 mol. Pemurnian hasil sintesis dilakukan dengan rekristalisasi menggunakan etanol dan aquades dingin. Struktur senyawa hasil sintesis ditentukan dengan cara spektrofotometri UV-Vis, spektrometri Inframerah, spektrometri Resonansi Magnetik Inti ( $\left.{ }^{1} \mathrm{H}-\mathrm{RMI}\right)$, dan GC-MS. Dari hasil penelitian menunjukkan bahwa rerata rendemen dari variasi jumlah mol $\mathrm{NaOH} 0,2 \mathrm{~mol} ; 0,4 \mathrm{~mol}$ dan $0,8 \mathrm{~mol}$ berturut-turut adalah
\end{abstract}


$(25,12 \pm 0,86) \%,(11,23 \pm 0,40) \%$ dan $(9,50 \pm 0,56) \%$. Rendemen paling optimal diperoleh pada jumlah mol katalis $\mathrm{NaOH} 0,2$ mol. Hasil uji Tukey menunjukkan adanya perbedaan yang signifikan pada masing-masing kelompok. Berdasarkan data spektrofotometri UVVis, spektrometri Inframerah, spektrometri ${ }^{1} \mathrm{H}-\mathrm{RMI}$, dan GC-MS menunjukkan bahwa senyawa yang dihasilkan adalah 2,6-bis(2'-hidroksibenzilidin) sikloheksanon.

Kata kunci: 2,6-bis(2'-hydroxybenzylidene)cyclohexanone, sintesis, katalis, rendemen

\section{PENDAHULUAN}

Senyawa kurkumin sudah banyak disintesis dengan mengubah sisi aktif dari senyawa kurkumin itu sendiri. Modifikasi struktur kurkumin dapat dilakukan dengan mengganti gugus fungsional pada salah satu sisi aktif dari kurkumin. Sisi aktif dari kurkumin yaitu sisi keton alifatik (gugus diketon) dan sisi inti benzen yang berada di kiri dan kanan dari sisi keton alifatik.

Modifikasi struktur dari kurkumin ini dilakukan untuk meningkatkan usaha pemanfaatan dari senyawa ini untuk pengobatan, sehingga ditemukan suatu modifikasi yang lebih berkhasiat dengan toksisitas lebih rendah (Van der goot, 1995). Salah satu turunan kurkumin yang terkenal yaitu senyawa Heksagamavunon (HGV). Senyawa ini merupakan hasil dari penggantian gugus diketon alifatik pada kurkumin menggunakan sikloheksanon. Penggantian ini dimaksudkan untuk mendapatkan senyawa aktif yang lebih stabil daripada kurkumin. Senyawa HGV yang pertama kali disintesis yaitu siklovalon. Senyawa 2,6-bis(4'-hidroksi3'-metoksibenzilidin) sikloheksanon atau yang lebih dikenal dengan Heksagamavunon-0 (HGV-0) merupakan salah satu senyawa hasil modifikasi dari kurkumin yang telah dikenal memiliki beberapa aktivitas farmakologi antara lain sebagai anti inflamasi, anti oksidan, dan anti bakteri (Sardjiman, 2000).

Pada sintesis ini merupakan modifikasi dari senyawa $\mathrm{HGV}-0$ (siklovalon) yaitu dengan menggunakan starting material 2-hidroksibenzaldehid dan sikloheksanon. Penggunaan sikloheksanon dimaksudkan untuk mempertahankan kestabilan senyawa, sedangkan rantai samping pada senyawa HGV-0 dimodifikasi dengan menghilangkan gugus metoksi pada posisi meta dan merubah posisi gugus hidroksi para pada rantai samping menjadi posisi orto. Pada sintesis ini menggunakan katalis natrium hidroksida untuk mempercepat terjadinya reaksi. Variasi jumlah mol katalis natrium hidroksida dilakukan untuk mendapatkan jumlah mol natrium hidroksida yang optimum yang dibutuhkan dalam sintesis 2,6-bis(2'-hidroksibenzilidin) sikloheksanon.

\section{METODE PENELITIAN}

\section{Peralatan}

Peralatan yang digunakan untuk sintesis senyawa 2,6-bis(2'hidroksibenzilidin) sikloheksanon adalah labu alas bulat leher tiga $250 \mathrm{~mL}$, pendingin spiral, motor pengaduk, propipet, pipet ukur $1 \mathrm{~mL}, 2 \mathrm{~mL}$, dan 10 $\mathrm{mL}$, timbangan elektrik, corong Bûchner, labu hisap, dan peralatan gelas lain. Peralatan untuk uji senyawa hasil sintesa yaitu spektrofotometer uv-vis, spektrometer inframerah SHIMADZU FTIR-8201 PC, spektrometer ${ }^{1} \mathrm{H}-\mathrm{RMI}$ $J E O L-M Y 60$, spektrometer massa GCMSQP2010S SHIMADZU.

\section{Bahan}

Bahan-bahan yang digunakan dalam sintesis senyawa 2,6-bis(2'hidroksibenzilidin)sikloheksanon adalah 2-hidroksibenzaldehid (Merck), sikloheksanon (Merck), $\mathrm{NaOH} 30 \%$ (Merck), $\mathrm{HCl} 1 \mathrm{~N}$ (Merck), dan aquadest dingin. Bahan untuk rekristalisasi 
senyawa hasil sintesis ialah etanol $96 \%$ (Merck) dan aquadest dingin. Bahan untuk uji spektrometri adalah dimetilsulfoksida (DMSO-d6), kalium bromida, dan etanol.

\section{Sintesis, isolasi dan pemurnian 2,6- bis(2'-hidroksibenzilidin) sikloheksanon}

Sintesis senyawa 2,6-bis(2'hidroksibenzilidin)sikloheksanon

dilakukan dengan cara mereaksikan sikloheksanon $1,5603 \mathrm{~mL}(0,015 \mathrm{~mol})$ dengan $\mathrm{NaOH} 6,00 \mathrm{~mL}(0,2 \mathrm{~mol}), 12,00$ $\mathrm{ml}(0,4 \mathrm{~mol}), 24,01 \mathrm{~mL}(0,8 \mathrm{~mol})$ yang kemudian dicatat sebagai variasi 1,2 , dan 3 dalam labu alas bulat leher tiga yang dilengkapi dengan pendingin balik. Labu alas bulat leher tiga dimasukkan ke dalam baskom air dengan suhu $25-30^{\circ} \mathrm{C}$ dan diaduk dengan kecepatan $1000 \mathrm{rpm}$ selama 1 jam. Kemudian ditambahkan tetes demi tetes 2-hidroksibenzaldehid sebanyak $3,14 \mathrm{~mL}(0,03 \mathrm{~mol})$ sampai habis lalu diaduk lagi selama 30 menit dan dilakukan pendiaman selama 2 hari pada suhu kamar. Isolasi produk sintesis dilakukan dengan menambahkan aquadest dingin ke dalam labu alas bulat secukupnya kemudian dipindahkan ke dalam mortir. Di dalam mortir senyawa digerus kemudian diteteskan $\mathrm{HCl} 1 \mathrm{~N}$ sampai tidak terbentuk endapan. Endapan yang diperoleh dipisahkan kemudian ditambahkan aquadest untuk menghilangkan sisa basa, sambil dilakukan penggerusan senyawa di dalam mortir. Senyawa disaring dengan corong buchner yang dilengkapi dengan kertas saring. Endapan kemudian dikeringkan didalam oven pada suhu $40{ }^{\circ} \mathrm{C}$ selama 24 jam. Senyawa 2,6-bis(2'hidroksibenzilidin)sikloheksanon

dilarutkan dengan etanol kemudian dipanaskan, dan setelah kristal semua larut kemudian disaring segera ditambahkan dengan aquadest dingin, lalu dimasukkan ke dalam baskom es untuk mempercepat terbentuk endapan. Kemudian disaring dengan corong buchner, dikeringkan didalam oven. Endapan senyawa hasil sintesis yang murni kemudian ditimbang dan dihitung rendemennya sebagai pure product dengan cara berat kristal hasil pemurnian dibandingkan dengan 2,6-bis(2'hidroksibenzilidin)sikloheksanon yang dihasilkan secara teoritis dan dikalikan $100 \%$.

\section{Spektrometri Inframerah}

Pada pengujian spektrometri inframerah ini dilakukan dengan pembuatan pelet $\mathrm{KBr}$. Pelet $\mathrm{KBr}$ dibuat dengan cara menumbuk cuplikan dengan $\mathrm{KBr}$ kemudian ditekan hingga diperoleh pelet. $\mathrm{KBr}$ harus kering dan akan lebih baik jika penumbukan dilakukan dibawah lampu inframerah untuk mencegah terjadinya kondensasi uap dari atmosfer yang akan memberikan serapan lebar pada $3500 \mathrm{~cm}^{-1}$. Pelet diletakkan dalam container sample dan dibaca serapannya.

\section{Spektrometri Resonansi Magnetik Inti $\left({ }^{1}\right.$ H-RMI)}

Senyawa uji dilarutkan dalam dimetilsulfoksida (DMSO-d6). Setelah itu larutan dimasukkan dalam tabung RMI dan dibaca serapannya.

\section{Analisis GC-MS}

Senyawa hasil sintesis dilarutkan dalam etanol kemudian cuplikan ini diinjeksikan ke dalam injektor. Aliran gas dari gas pengangkut (fase gerak) akan membawa cuplikan yang telah teruapkan masuk ke dalam kolom. Kolom akan memisahkan komponen-komponen dari cuplikan. Komponen dideteksi oleh detektor dan sinyal dalam bentuk puncak. Fase diam yang digunakan berupa cairan yang bersifat polar yaitu polieter. Senyawa hasil sintesis yang telah murni dan kering dilarutkan dalam aseton kemudian dimasukkan ke dalam tabung spektrometri massa. Senyawa masuk pada tekanan rendah dan dipanaskan menjadi bentuk gas. Senyawa dalam bentuk gas ditembak dengan seberkas 
elektron dengan kekuatan energi sekitar $70 \mathrm{eV}$. Tembakan ini menyebabkan lepasnya sebuah elektron, menghasilkan radikal kation yang disebut ion molekul. Pada umumnya ion molekul tidak stabil dan mudah melepaskan energi dengan cara berfragmentasi.

\section{HASIL DAN PEMBAHASAN}

\section{Rendemen senyawa 2,6-bis(2'- hidroksibenzilidin)sikloheksanon}

Senyawa

2,6-bis $\left(2^{\prime}-\right.$

hidroksibenzilidin)sikloheksanon

disintesis melalui kondensasi 2hidroksibenzaldehid dan sikloheksanon dengan katalis basa $\mathrm{NaOH}$ merupakan jenis reaksi aldol campuran atau yang sering disebut reaksi Claisen-Schmidt. Pada sintesis 2,6-bis(2'hidroksibenzilidin)sikloheksanon, jumlah mol dari starting material 2hidroksibenzaldehid dibuat dua kali lebih besar $(0,03 \mathrm{~mol})$ dari jumlah mol reaktan sikloheksanon $(0,015 \mathrm{~mol})$ hal ini dilakukan agar diperoleh produk atau hasil sintesis sesuai yang diinginkan yaitu 2,6-bis(2'-hidroksibenzilidin)

sikloheksanon, karena sikloheksanon sebagai nukleofil mempunyai 2 karbon yang merupakan sumber hidrogen $\alpha$ yang sama-sama reaktif yang dapat bereaksi dengan 2 buah molekul aldehid yaitu 2hidroksibenzaldehid. Katalisator yang digunakan adalah natrium hidroksida yang divariasi jumlah molnya, yaitu 0,2 mol; 0,4 mol dan 0,8 mol. Secara teori, semakin besar mol basa, maka akan semakin banyak ion enolat dan tumbukan yang terjadi dan menyebabkan produk yang terbentuk semakin banyak.

Tabel 1 Hasil Rendemen senyawa 2,6-bis(2'-hidroksibenzilidin)sikloheksanon pada masing-masing kelompok

\begin{tabular}{|c|c|c|c|c|c|c|}
\hline Kelompok & Replikasi & $\begin{array}{l}\text { Hasil } \\
\text { isolasi } \\
\text { (gram) }\end{array}$ & $\begin{array}{c}\text { Hasil } \\
\text { pemurnian } \\
\text { (gram) }\end{array}$ & $\begin{array}{c}\text { (Rerata } \\
\pm \mathrm{SD}) \\
\text { gram }\end{array}$ & $\begin{array}{c}\text { Rendemen } \\
(\%)\end{array}$ & $\begin{array}{r}\text { (Rerata } \\
\pm \mathrm{SD}) \%\end{array}$ \\
\hline I & 1 & 0,5620 & - & - & 12,36 & - \\
\hline \multirow{3}{*}{ II } & 1 & 2,3847 & 1,1786 & \multirow{3}{*}{$\begin{array}{c}1,1419 \pm \\
0,0389\end{array}$} & 25,93 & \multirow{3}{*}{$\begin{array}{c}25,12 \pm \\
0,86\end{array}$} \\
\hline & 2 & 2,3853 & 1,1461 & & 25,22 & \\
\hline & 3 & 2,3310 & 1,1010 & & 24,22 & \\
\hline \multirow{3}{*}{ III } & 1 & 1,5738 & 0,4923 & \multirow{3}{*}{$\begin{array}{c}0,5103 \pm \\
0,0181\end{array}$} & 10,83 & \multirow{3}{*}{$\begin{array}{c}11,23 \pm \\
0,40\end{array}$} \\
\hline & 2 & 1,6293 & 0,5285 & & 11,63 & \\
\hline & 3 & 1,6061 & 0,5102 & & 11,22 & \\
\hline \multirow{3}{*}{ IV } & 1 & 1,0889 & 0,4607 & \multirow{3}{*}{$\begin{array}{c}0,4321 \pm \\
0,0254\end{array}$} & 10,13 & \multirow{3}{*}{$\begin{array}{c}9,503 \pm \\
0,56\end{array}$} \\
\hline & 2 & 1,0285 & 0,4236 & & 9,32 & \\
\hline & 3 & 1,0168 & 0,4120 & & 9,06 & \\
\hline
\end{tabular}

\section{Keterangan:}

Kelompok I : hasil sintesis dengan mol katalis $\mathrm{NaOH} \mathrm{0,1} \mathrm{mol}$

Kelompok II : hasil sintesis dengan mol katalis $\mathrm{NaOH} \mathrm{0,2} \mathrm{mol}$

Kelompok III : hasil sintesis dengan mol katalis $\mathrm{NaOH} 0,4 \mathrm{~mol}$

Kelompok IV : hasil sintesis dengan mol katalis $\mathrm{NaOH} \mathrm{0,8} \mathrm{mol}$

Pemurnian dilakukan dengan metode rekristalisasi untuk memperoleh kristal yang murni. Metode rekristalisasi yang digunakan adalah mengkristalkan secara langsung dari cairan pelarut. Hasil dari pemurnian senyawa hasil sintesis dan rendemennya dapat dilihat pada Tabel I.
Hasil uji tukey menunjukkan adanya perbedaan yang signifikan pada masingmasing kelompok.

Rendemen yang diperoleh tidak mencapai $100 \%$ dikarenakan terjadinya kondensasi diri sikloheksanon, terjadinya monosubtitusi pada sikloheksanon oleh 
2-hidroksibenzaldehid karena reaksinya belum sempurna, dan sesuai dengan konsep Arhenius bahwa tidak semua molekul-molekul yang bertumbukan menghasilkan tumbukan yang efektif yang dapat menghasilkan produk.

\section{Spektrometri Inframerah, $\left({ }^{1} \mathrm{H}-\mathrm{RMI}\right)$, dan Analisis GC-MS}

Pemeriksaan

dengan spektrofotometri uv-visibel dilakukan untuk melihat ada tidaknya pergeseran panjang gelombang senyawa hasil sintesis dan starting material. Spektra uvvis starting material dan senyawa hasil sintesis dapat dilihat pada gambar 2 dan 3.

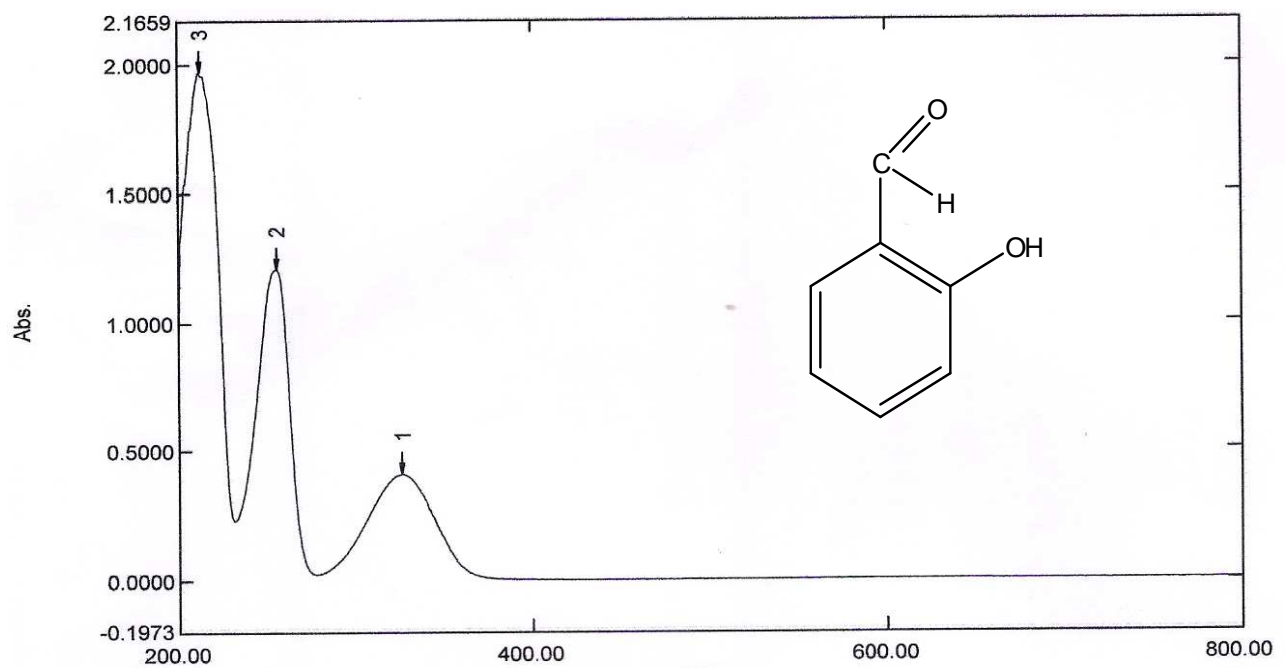

Gambar 1. Spektra uv-vis senyawa 2-hidroksibenzaldehid

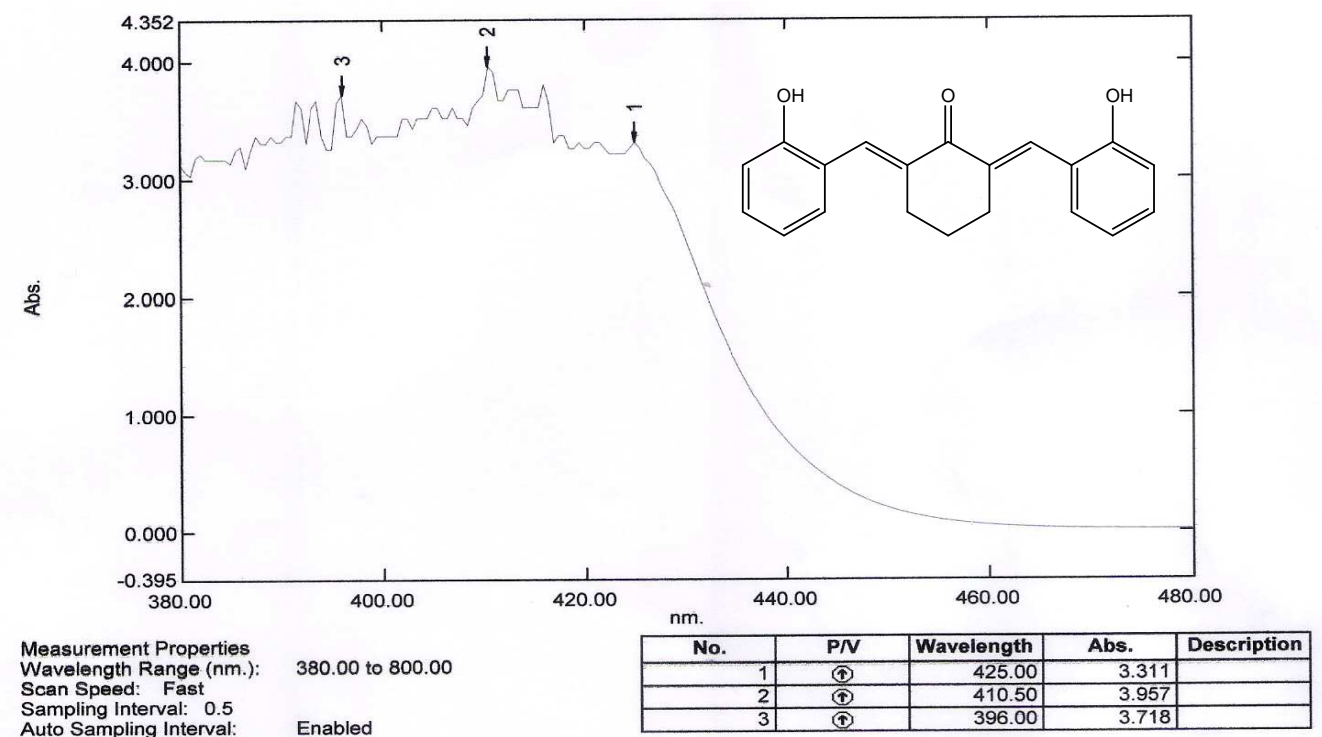
Auto Sampling Interva: Scan Mode: Single

Enabled

Samnla Pranaration Pronerties

Gambar 2. Spektra uv-vis pada senyawa hasil sintesis 


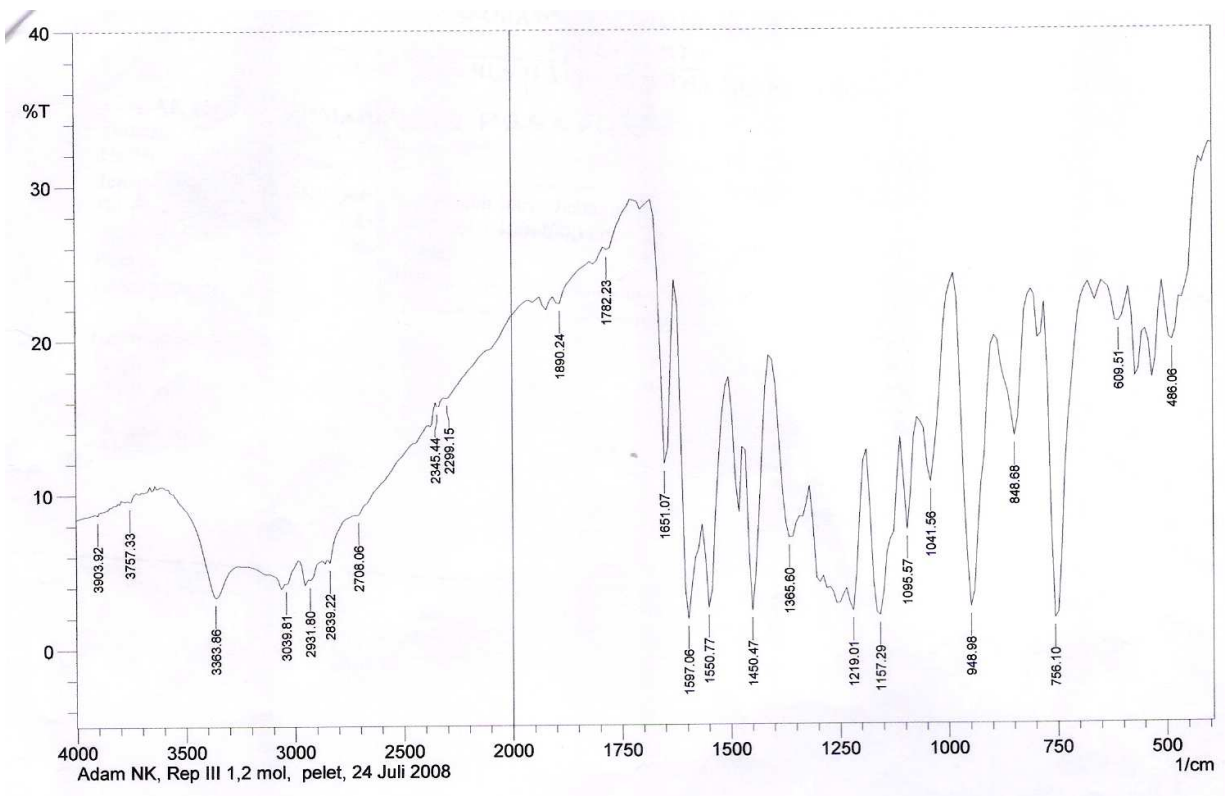

Gambar 3. Spektra IR senyawa hasil sintesis

Tabel 2. Jenis Vibrasi pada Spektra IR

\begin{tabular}{ccc}
\hline Bilangan Gelombang $\left(\mathrm{cm}^{-1}\right)$ & Intensitas & Jenis Vibrasi Gugus Fungsional \\
\hline 3363,86 & kuat & Vibrasi rentangan $\mathrm{OH}$ \\
3039,81 & sedang & Vibrasi rentangan $\mathrm{CH}$ aromatik \\
2931,80 & lemah & Vibrasi rentangan $\mathrm{CH}$ alifatik \\
1597,06 & kuat & Vibrasi rentangan $\mathrm{C}=\mathrm{O}$ terkonjugasi \\
1450,47 & kuat & Vibrasi rentangan $\mathrm{C}=\mathrm{C}$ aromatik \\
1157,29 & kuat & Vibrasi rentangan C-O \\
946,98 & sedang & Vibrasi keluar bidang $=\mathrm{C}-\mathrm{H}$ alken \\
756,10 & kuat & Vibrasi bengkokan C-H keluar bidang pada \\
& & benzene disubstitusi orto \\
\hline
\end{tabular}

Hasil dari pemeriksaan spektrofotometri uv-vis terhadap senyawa hasil sintesis menunjukkan adanya adanya pergeseran panjang gelombang kearah yang lebih panjang (bathochromic shift) dengan $\lambda_{\text {maks }}$ senyawa hasil sintesis adalah $410,5 \mathrm{~nm}$, sedangkan $\lambda_{\text {maks }} 2$ hidroksibenzaldehid sebesar $326 \mathrm{~nm}$.

Untuk menentukan bahwa struktur senyawa hasil sintesis adalah 2,6-bis(2'-hidroksibenzilidin)

sikloheksanon, maka dilakukan pemeriksaan senyawa secara spektrometri Inframerah, spektrometri Resonansi Magnetik Inti dan Spektrometer massa.

Dari data spektra inframerah tersebut dapat diketahuio gugus-gugus fungsi yang terdapat dalam senyawa hasil sintesis. Pita kuat dan lebar pada bilangan gelombang 3363,86 $\mathrm{cm}^{-1}$ terdapat gugus $\mathrm{OH}$ yang pita gelombang normalnya terdapat pada 3600-3400 $\mathrm{cm}^{-1}$ (Sastrohamidjojo, 2001). Adanya pita serapan pada $3039,81 \mathrm{~cm}^{-1}$ dengan intensitas sedang, pita tersebut menunjukkan adanya $\mathrm{CH}$ aromatis. Hal ini diperkuat dengan munculnya pita serapan pada 1450,47 $\mathrm{cm}^{-1}$ dengan intensitas kuat yang menunjukkan adanya gugus $\mathrm{C}=\mathrm{C}$ aromatik. Pada spektra hasil sintesis, pita serapan $\mathrm{CH}$ alifatik muncul pada 2931,80 $\mathrm{cm}^{-1}$ dengan intensitas sedang. Pada bilangan gelombang $1597,06 \mathrm{~cm}^{-1}$ adanya pita dengan intensitas kuat menunjukkan adanya gugus karbonil dari keton terkonjugasi 
ikatan rangkap ( $\mathrm{C}=\mathrm{O}, \alpha, \beta$ tak jenuh), pita karbonil keton normal umumnya terdapat pada $1715 \mathrm{~cm}^{-1}$ (Sastrohamidjojo, 2001). Hal ini disebabkan karena adanya efek resonansi sehingga menurunkan karakter ikatan rangkap $\mathrm{C}=\mathrm{O}$. Hasilnya frekuensi vibrasi menjadi turun. Vibrasi rentangan C-O ditandai dengan munculnya serapan pada $1157,29 \mathrm{~cm}^{-1}$ dengan intensitas kuat. Vibrasi dengan intensitas sedang pada daerah 946,98 $\mathrm{cm}^{-1}$ memperkuat adanya alkena, yang pada umumnya muncul pada daerah 1000 hingga $650 \mathrm{~cm}^{-1}$. Pada daerah 756,10 $\mathrm{cm}^{-1}$ muncul vibrasi bengkokan $\mathrm{C}-\mathrm{H}$ keluar bidang pada benzen disubstitusi orto dengan intensitas kuat.

Untuk memperoleh informasi yang lebih lengkap mengenai senyawa sintesis ini maka dilakukan pengujian ${ }^{1} \mathrm{H}$ RMI. Di bawah ini adalah pola ${ }^{1} \mathrm{H}-\mathrm{RMI}$ senyawa hasil sintesis terlihat pada gambar 4.

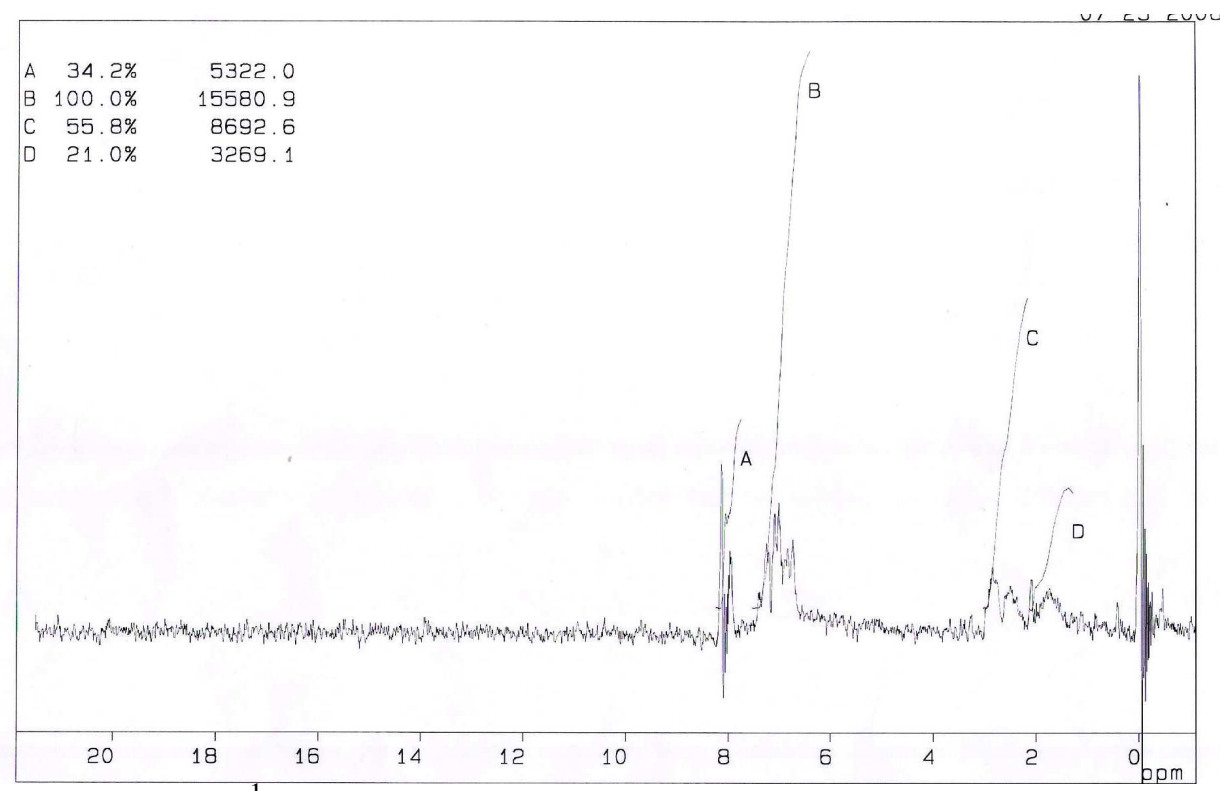

Gambar 4. Spektra ${ }^{1}$ H-RMI senyawa hasil sintesis

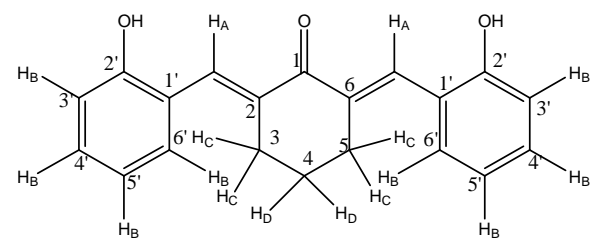

Tabel 3. Data jenis proton hasil spektra ${ }^{1} \mathrm{H}-\mathrm{RMI}$

\begin{tabular}{cccccc}
\hline Jenis & \multicolumn{2}{c}{ Adams (2004) } & \multicolumn{2}{c}{ Hasil percobaan } & \multirow{2}{*}{ Jenis proton } \\
\cline { 2 - 5 } puncak & $\delta$ & splitting & $\delta$ & splitting & \\
\hline A & 7,98 & $s$ & $8,3-7,8$ & $s$ & $2 \mathrm{H}_{\mathrm{A}}$ dari $\mathrm{H} \beta$ \\
B & 7,32 & $d d$ & $7,5-6,5$ & $m$ & $8 \mathrm{H}_{\mathrm{B}}$ dari cincin \\
& 7,19 & $t d$ & & & aromatis \\
& 6,86 & $m$ & & & $4 \mathrm{H}_{\mathrm{C}}$ dari $2 \mathrm{CH}_{2}-\mathrm{CH}_{2}$ \\
C & 2,86 & $m$ & 2,8 & $m$ & $2 \mathrm{H}_{\mathrm{D}}$ dari $\mathrm{CH}_{2}$ \\
D & 1,75 & $m$ & 2,3 & $m$ & \\
\hline
\end{tabular}



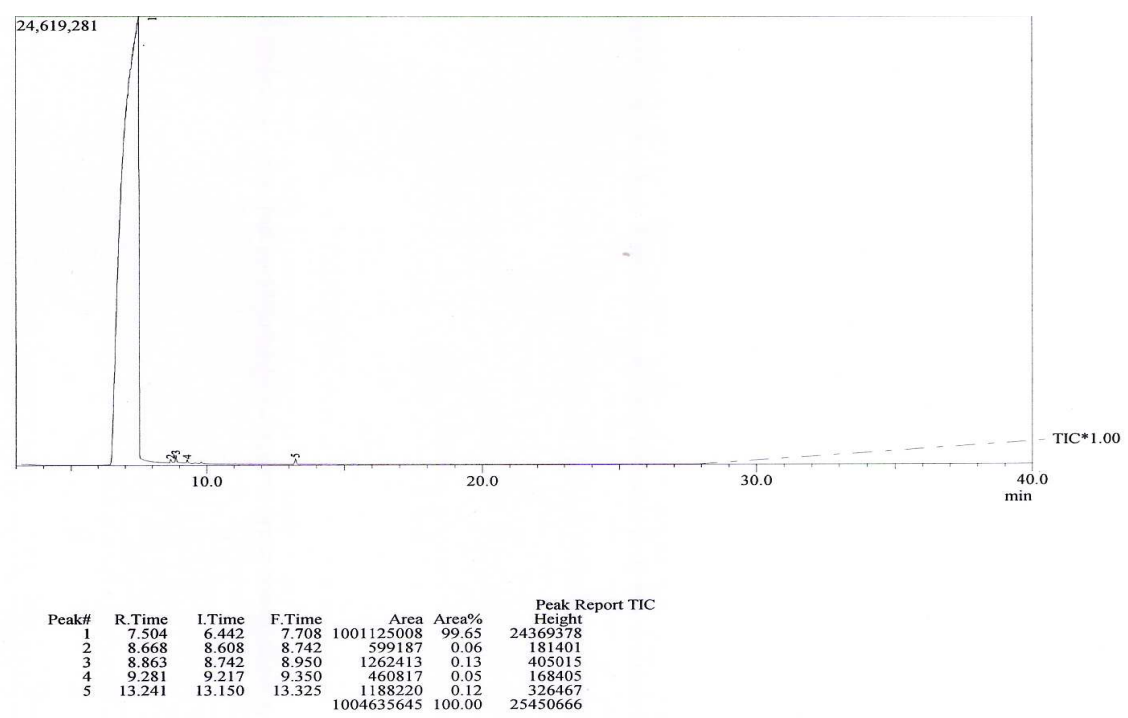

Gambar 5. Kromatogram senyawa hasil sintesis pada $\mathrm{NaOH} \mathrm{0,2} \mathrm{mol}$
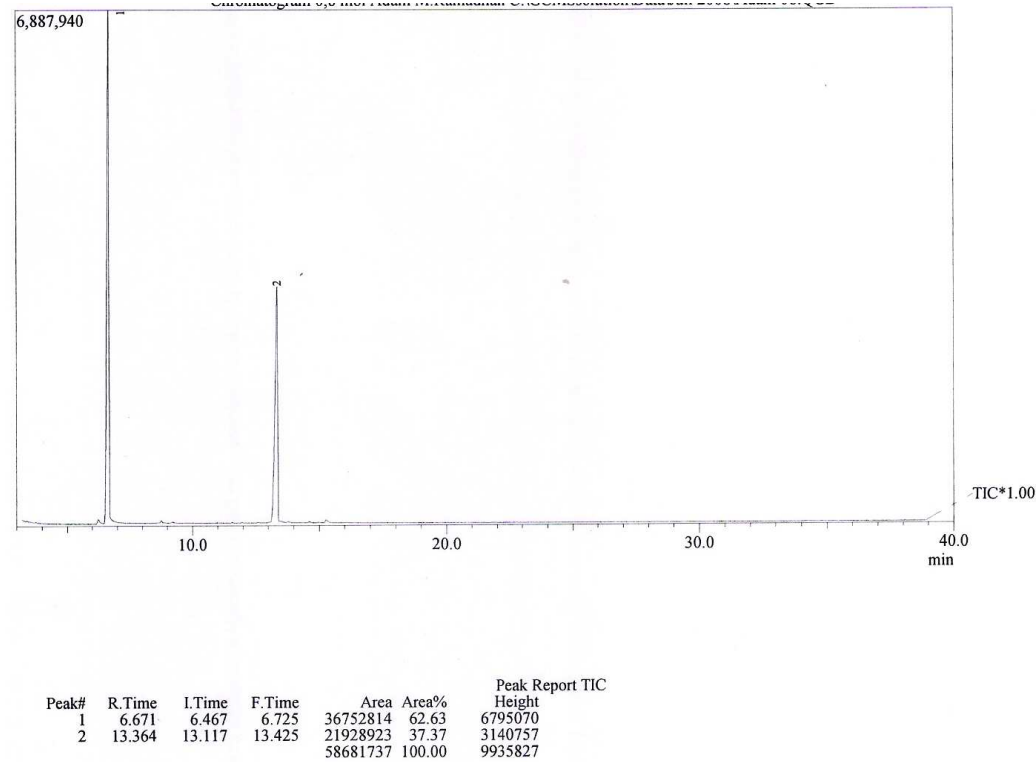

Gambar 6. Kromatogram senyawa hasil sintesis pada $\mathrm{NaOH} \mathrm{0,8} \mathrm{mol}$

Pada senyawa 2,6-bis $\left(2^{\prime}-\right.$ hidroksibenzilidin)sikloheksanon dengan katalis natrium hidroksida $20 \%$ (Adams, dkk) yang telah disintesis mempunyai pola splitting pada pergeseran kimia 7,98 menunjukkan adanya dua proton, pergeseran kimia 7,32 menunjukkan adanya dua proton, pergeseran kimia 7,19 menunjukkan adanya dua proton, pergeseran kimia 6,86 menunjukkan adanya empat buah proton, pergeseran kimia 2,86 menunjukkan adanya empat buah proton dan pergeseran kimia 1,75 menunjukkan adanya 2 buah proton.
Pengujian ${ }^{1} \mathrm{H}-\mathrm{RMI}$ memberikan informasi tentang jumlah atom-atom hidrogen yang terdapat pada senyawa sintesis. Pada spektra ${ }^{1} \mathrm{H}-\mathrm{RMI}$ senyawa hasil sintesis terlihat 4 puncak yang menunjukkan empat proton yang berbeda. Pergeseran kimia 8,3-7,8 ppm pada puncak A menunjukkan adanya dua proton $\mathrm{H} \beta$. Pada puncak ini muncul pada daerah downfield karena adanya efek resonansi dari gugus karbonil menyebabkan $C \beta$ bermuatan positif sehingga secara induktif kerapatan elektron $\mathrm{H} \beta$ berkurang. Pada puncak B dengan pergeseran 7,5-6,5 ppm 
menunjukkan adanya enam buah proton dari cincin aromatis yang letaknya simetris yaitu H-3', H-4', H-5', dan H-6'. Pada puncak $\mathrm{C}$ dengan pergeseran kimia 2,8 ppm menunjukkan adanya empat proton dari sikloheksanon yaitu C-3 dan C-5, sedangkan puncak D dengan pergeseran kimia 2,3 ppm menunjukkan dua proton dari sikloheksanon yaitu C-4. Posisi proton ini paling terlindungi oleh awan elektron karena letaknya didalam struktur yang cukup terisolasi dari gugusgugus ataupun kondisi yang dapat mengurangi kerapatan awan elektron seperti gugus penarik elektron. Sehingga geseran kimianya berada pada daerah upfield. Sedangkan untuk proton dari gugus hidroksi tidak tampak pada spektra, terjadinya proton exchange dengan pelarut DMSO-d6.

Uji kemurnian dilakukan juga dengan Gas Choramography. Senyawa dikatakan murni apabila muncul satu puncak tajam. Pada penelitian ini dilakukan dua variasi mol kromatografi gas yaitu 0,2 mol dan 0,8 mol tujuannya.
Hasil kromatografi gas dapat dilihat pada gambar $5(0,2 \mathrm{~mol})$ dan gambar $6(0,8$ mol).

Hasil kromatografi gas senyawa hasil sintesis dengan 0,2 mol diperoleh lima puncak, satu puncak dengan lebar puncak yang kecil dan tajam sedangkan puncak yang lain lebih kecil. Kemurnian senyawa hasil sintesis adalah 99,65\%. Sedangkan 0,8 mol diperoleh 2 puncak, satu puncak tampak tinggi dan sempit dengan kemurnian senyawa sintesis 62,63 $\%$ dan puncak yang lainnya lebih rendah mempunyai kemurnian $37,37 \%$.

Penentuan struktur senyawa hasil sintesis yang terakhir dengan menggunakan spektrometri massa. Dari spektrometri massa akan diperoleh bobot molekul dari senyawa sintesis dan fragmentasi molekulnya. Pada spektrometri massa ini digunakan dua variasi mol yaitu $0,2 \mathrm{~mol}$ dan $0,8 \mathrm{~mol}$. Spektra massa senyawa hasil sintesis ditunjukkan oleh gambar $7(0,2 \mathrm{~mol})$ dan gambar $8(0,8 \mathrm{~mol})$.

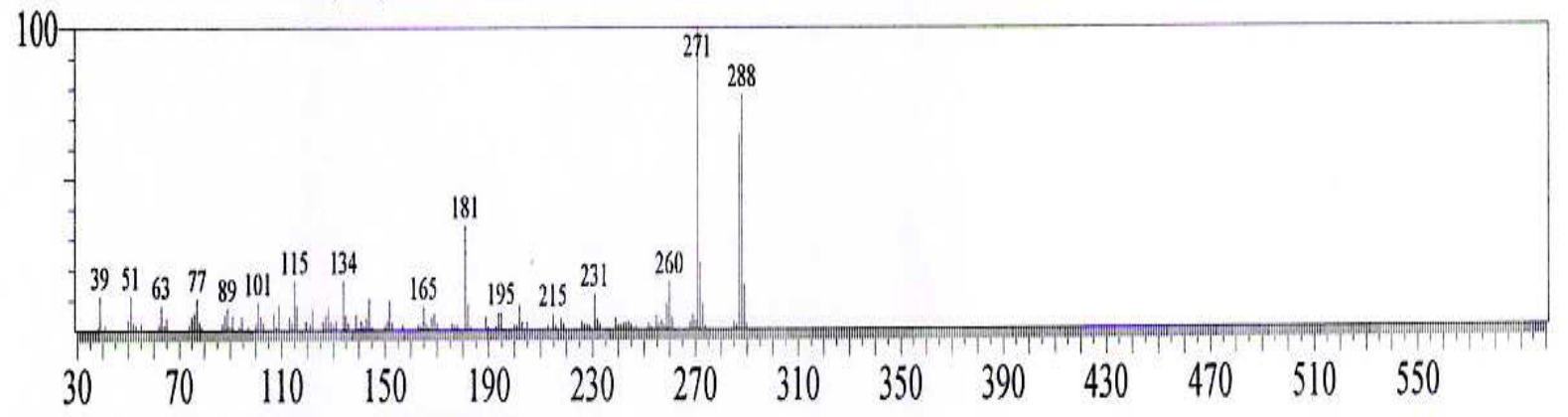

Gambar 7. Spektra massa senyawa hasil sintesis pada jumlah mol katalis $\mathrm{NaOH} \mathrm{0,2} \mathrm{mol}$

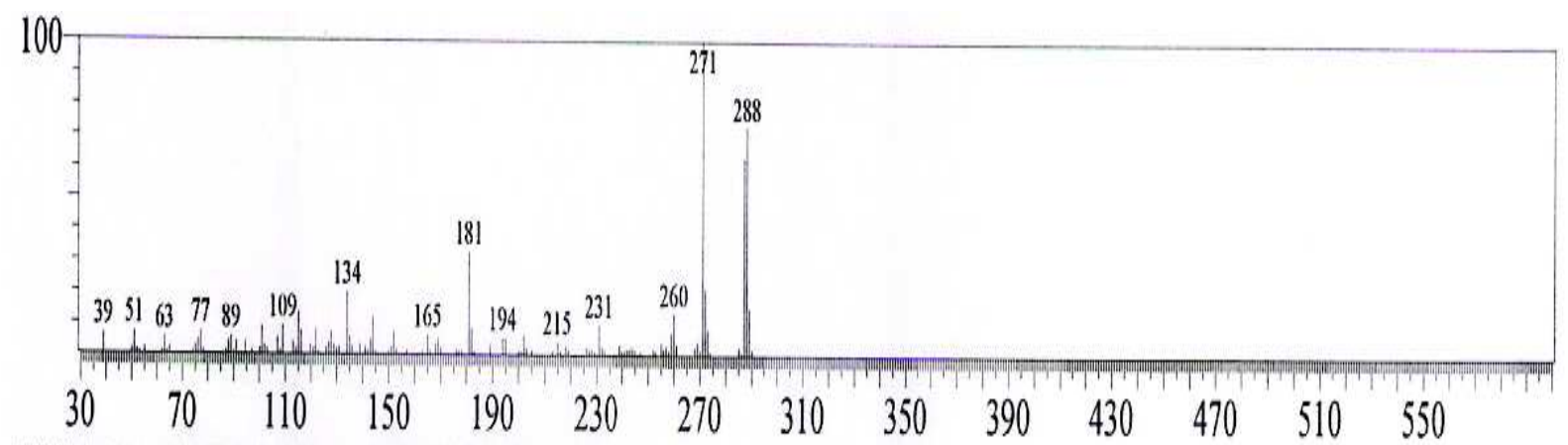

Gambar 8. Spektra massa senyawa hasil sintesis pada jumlah mol katalis $\mathrm{NaOH} \mathrm{0,8} \mathrm{mol}$ 
Pada variasi jumlah mol katalis (gambar 7) 0,2 mol dan (gambar 8) 0,8 mol mempunyai bobot molekul yang sama yaitu muncul puncak tertinggi sebesar 288. Senyawa 2,6-bis(2'hidroksibenzilidin)sikloheksanon

memiliki bobot molekul sebesar 306 . Puncak yang muncul adalah senyawa 2,6bis(2'-hidroksibenzilidin) sikloheksanon yang kehilangan $\mathrm{H}_{2} \mathrm{O}$ karena adanya gugus $\mathrm{OH}$ yang tidak stabil ketika ditembak oleh berkas elektron sehingga lepas sebagai molekul air $\left(\mathrm{H}_{2} \mathrm{O}\right)$ sehingga muncul puncak pada 288 dengan intensitas tinggi. Fragmentasi berikutnya yaitu melepaskan gugus $\mathrm{OH}$ yang ditunjukkan dengan puncak pada 271, muncul dengan intensitas tinggi pada spektra. Kemudian adanya resonansi sehingga muncul puncak pada 181 .

\section{KESIMPULAN}

Berdasarkan dari hasil penelitian yang telah dilakukan dapat disimpulkan sebagai berikut :

1. Senyawa 2,6-bis $\left(2^{\prime}-\right.$ hidroksibenzilidin)sikloheksanon dapat disintesis dari 2hidroksibenzaldehid dan sikloheksanon dengan katalis natrium hidroksida $30 \%$

2. Variasi jumlah mol katalis natrium hidroksida berpengaruh terhadap rendemen 2,6-bis( $2^{\prime}$ hidroksibenzilidin)sikloheksanon dengan rerata $(25,12 \pm 0,86) \%$ pada $0,2 \mathrm{~mol} ;(11,23 \pm 0,40) \%$ pada $0,4 \mathrm{~mol}$ dan $(9,50 \pm 0,56)$ pada $0,8 \mathrm{~mol}$

3. Rendemen maksimal diperoleh pada jumlah mol 0,2 mol sebesar $(25,12 \pm 0,86) \%$

\section{SARAN}

1. Perlunya dilakukan pengkajian lebih lanjut stabilitas senyawa 2,6bis(2'-hidroksibenzilidin) sikloheksanon.
2. Penelitian metode rekristalisasi untuk mendapatkan rendemen yang tinggi dan kristal yang bebas dari pengotor.

3. Perlu dilakukan KLT preparatif untuk mendapatkan senyawa yang lebih murni

\section{DAFTAR PUSTAKA}

1. Adams, K., Brian, dkk, 2004, Synthesis and biological evaluation of novel curcumin analogs as anticancer and anti-angiogenesis agents, Biorganic and Medical Chemestry 12, USA, 3871-3883

2. Anonim, 1995, Farmakope Indonesia, Edisi III, Jakarta: Departemen Kesehatan Republik Indonesia.

3. Carey, A,F., and Sundberg, R.J, 1990, Advanced Organic Chemistry, Third edition, part B, Structure and Mechanism, Plenum Press, New York, 55,58-60.

4. Mackenzie, 1967, Experimental Organic Chemistry, third edition, Prentice hall, inc, Englewood cliffc, N.J., 1-3.

5. Majeed, Muh., Badmaev, V., Shivakumar, U., Rajendran, R., 1995, Curcuminoids- Antioxidant Phytonutrients, Nutriscience Publishers Inc., Piscataway, New Jersey.,7-10,15.

6. Sardjiman, 2000, Synthesis of Some New Series of Curucumin Analogues, Antioxidative, Antiinflammatory, Antibacterial, Activities and Qualitative Structure Activity Relationship, A Disertation, Departement of Pharmaceutical, Gadjah Mada University, Yogyakarta, hal 625-628.

7. Sastrohamidjodjo, Hardjono, 1985, Kromatografi, Liberty, Yogyakarta., 26-30,41,43. 
8. Sastrohamidjodjo, Hardjono, 2001, Spektroskopi, Ed. 2, Liberty, Yogyakarta., 54-56,119,163-165.
9. Van Der Goot, 1995, The Chemistry and Qualitative Structure Activity Relationship of Curcumin, In Pramono S. (editor), Recent Development in Curcumin Pharmacochemistry, p.13, Faculty of Pharmacy Gadjah Mada University, Aditya Media, Yogyakarta. 